\title{
Sosyal İş Modelleri ve Sosyal Girişimcilik: Boğaziçi Üniversitesi Tüketim Kooperatifi Örneği (Social Business Models and Social Entrepreneurship: Boğaziçi University Consumption Cooperative Case)
}

\section{Çiğdem KAYA iDa}

a İstanbul Arel Üniversitesi, İstanbul, Türkiye, cigdemkaya2810@gmail.com

\begin{tabular}{ll}
\hline MAKALE BİLGísí \\
\hline Anahtar Kelimeler: \\
Sosyal Girişimcilik
\end{tabular}

\section{ÖZET}

Amaç - Sosyal ihtiyaçları karşılayan ve yeni sosyal ilişkiler ve işbirlikleri yaratan yeni fikirler sosyal inovasyonlardır ve sosyal girişimciler aracilığıyla hayat bulmaktadırlar. Günümüzün sürekli değişen ve gelişen toplumsal yapısında devletin yeterli olamadığı alanlarda temel insan ihtiyaçlarını karşılayabilmek için yeni iş modelleri yaratan kuruluşlardan olan Sivil Toplum Kuruluşları da (STK) bu değişim ve gelişime ayak uydurarak sosyal girişimcilik örnekleri sergilemektedirler. $\mathrm{Bu}$ çalışmada sosyal iş modeli ve sosyal girişimcilik yazınından yararlanarak alternatif bir iş modeli benimseyen Boğaziçi Üniversitesi Tüketim Kooperatifi (BÜKOOP) incelenmiştir.

Yöntem - Bu çalışmada, gıda alanındaki küçük üreticileri tüketiciler ile aracılar olmaksızın buluşturan alternatif bir iş modeli biçimlendiren ve farklı örgütlenme biçimleri sergileyen Boğaziçi Üniversitesi Tüketim Kooperatifi örnek olay yöntemiyle incelenmiştir. Çalışmada ikincil veri

\section{Makale Kategorisi:}

Araştırma Makalesi kaynaklarından (BÜKOOP hakkında çıkan haberler, yapılan mülakatlar, yazılan bilimsel makaleler, BÜKOOP web sitesinde yer alan bilgilerden) yararlanılmıştır.

Bulgular - BÜKOOP'un bu sosyal girişimin nasıl ve ne amaçla başlatıldığı, hayata geçirirken hangi tür çalışmaların yapıldı ̆̆ı, bu çalışmaların nasıl yapıldığı, girişimin örgüt yapısı ve faaliyetleri Tracey, Phillips ve Jarvis'in (2011) kurumsal girişimcilerin yeni bir örgüt formu oluşturmaları sırasında yapmış oldukları çalışmalara odaklanarak geliştirdikleri modelden yararlanılarak ortaya konmaya çalışılmıştır. Ayrıca Sosyal İş Modeli Kanvas'ından (Kent State University, 2019) ve Osterwalder ve Pigneur'un (2010) iş modeli kanvasından yararlanarak BÜKOOP sosyal iş modeli elde edilen veriler çerçevesinde açıklanmaya çalışılmıştır.

Tartışma - Boğaziçi Üniversitesi mensupları tarafından kurulan ve sağlıklı gıdayı uygun fiyatla aracısız olarak tüketiciye sunmayı amaçlayan ve bu çalışmaları yerine getiren BÜKOOP'un sosyal girişimci bir yapıda olduğu ifade edilebilir. Sonuç olarak bu çalışmada sosyal girişimcilik yoluyla yeni bir sosyal iş modelinin oluşturulmasına odaklanılmıştır.

\begin{tabular}{l}
\hline ARTICLE INFO \\
\hline Keywords: \\
Social Entrepreneurship \\
Social Business Model \\
Consumption Cooperative
\end{tabular}

Received 4 May 2019

Revised 3 July 2019

Accepted 25 July 2019

\section{ABSTRACT}

Purpose - New ideas that meet social needs and create new social relationships and collaborations are social innovations and come to life through social entrepreneurs. In today's constantly changing and developing social structure, non-governmental organizations (NGOs), which create new business models to meet basic human needs in areas where the state is not sufficient, exhibit examples of social entrepreneurship by keeping up with this change and development. Drawing from social business model and social entrepreneurship literature, Boğaziçi University Consumption Cooperative (BÜKOOP) which uses an alternative business is examined in this study.

Design/Methodology/Approach - In this study, Boğaziçi University Consumption Cooperative, which forms an alternative business model that brings together small producers in the field of food without consumers and intermediaries, has been examined by case study method. Secondary data sources (news, interviews, scientific articles about BÜKOOP, and information on BÜKOOP website) were used in the study.

Findings - How and for what purpose BÜKOOP launched this social enterprise, what kind of activities were carried out while performing, how these works were done, the organizational structure and activities of the enterprise were tried to be revealed by using the model developed by Tracey, Phillips and Jarvis (2011) by focusing on "work" done during formation a new organizational form. In addition, BÜKOOP social business model was explained by using the Social Business Model Canvas (Kent State University, 2019) and the business model canvas of Osterwalder and Pigneur (2010).

Discussion - It can be stated that BÜKOOP has aimed to provide healthy food to the consumer at an affordable price without intermediaries and perform these activities with a social entrepreneurial structure. In conclusion, this study focused on the creation of a new social business model through social entrepreneurship. 


\section{Giriş}

Sosyal girişimcilik araştırmacılar tarafından son yıllarda odaklanılan alanlardan biri olmuştur. Sosyal girişimcilik oluşturulan sosyal iş modelleriyle toplumda sürdürülebilir kalkınmayı amaçlayan önemli bir girişimcilik alanı haline gelmiştir. "Sosyal girişimcilik" terimi, mevcut pazarların ve kurumların tatmin edemediği temel insan ihtiyaçlarını etkin bir şekilde karşılamak için modeller yaratmış olan hızla artan sayıda kuruluşlara atıfta bulunmaktadır. Sosyal girişimcilik, geleneksel girişimciliğin kaynakları harekete geçirme becerikliliğini toplumu değiştirme misyonuyla birleştirmektedir (Seelos ve Mair, 2005:241). Sosyal girişimcilerin faaliyetleri, modern toplumun ekonomik, sosyal ve politik alanlarındaki değişimlerin güçlendirilmesi zeminine odaklanmıştır. Son yıllarda sosyal girişimciler sosyal, finansal veya ekonomik dışlanmanın azaltılmasında, sağlık hizmetlerine erişimin sağlanmasında ve insanların işgücü piyasasına yeniden entegre edilmesinde, uzak bölgelerin ve toplulukların canlandırılmasında, çevre koruma çözümlerinin üretilmesinde aktif rol oynamaktadır. Sosyal girişimcilerin rolü, iş geliştirme ve yeni sosyal iş modelleriyle sosyal ve ekonomik büyüme ve sürdürülebilir çevresel kalkınmayı üretecek araçları sağlamaktır (Navasaitiene, Vishniakova Rukuiziene, 2016: 404).

Sosyal girişimciler, etkin Sivil Toplum Kuruluşları (STK'lar) ve etkili bireyler aracılığıyla devlet ve işletmeler tarafından bırakılan boşlukları doldurmaya çalışmaktadırlar. Başlangı̧̧ta dayanışma, protesto ve kent yaşamında ayakta kalmak için dayanışma misyonlarıyla belirginleşen STK'lar, bugün yaşamın her alanında işlev gören bir kimliğe bürünmüşlerdir. Gönüllülük temelinde, bir özel misyon bağlamında kâr amaçsız olarak kurulan STK'lar, kamu ve özel sektörün yanı sıra, üçüncü sektör olarak yaşamın her alanında gözlenmektedirler. Demokrasi, insan hakları, çevre, göçmen hakları gibi alanlarda görev üstlendikleri gibi, ekonomik alanda da değer yaratmaktadırlar. Bu nedenle de üçüncü sektör olarak anılmaktadırlar (Akdemir ve Kaya, 2018: 881) ve "açıklık, katılımcılık, şeffaflık, hesap verebilirlik, etkin olmak ve tutarlılık" gibi ilkeler (Kaya, 2008: 22) çerçevesinde faaliyet göstermektedirler.

STK'lar ve etkili bireyler aracıllğıyla hayata geçirilen sosyal girişimcilik, akademik bir konu olarak ivme kazanmaktadır. Geçtiğimiz on yılda, çok sayıda okul, özellikle işletme okulları bu konuda yeni kurslar, programlar, merkezler veya araştırma girişimleri başlatmıştır. Bu çalışmalar her ne kadar yoğunlaşsa bile, entelektüel sorgulama alanı olarak, sosyal girişimcilik henüz başlangıç aşamasındadır (Dees ve Anderson, 2006: 39). Dolayısıyla alanın olgunlaşabilmesi için derin, zengin açıklayıcı çalışmalara bu alanda ihtiyaç vardır. Bu çalışmada, gıda alanındaki küçük üreticileri tüketiciler ile aracılar olmaksızın buluşturan alternatif bir iş modeli biçimlendiren ve farklı örgütlenme biçimleri sergileyen bir STK olan Boğaziçi Üniversitesi Tüketim Kooperatifi (BÜKOOP) incelenmiştir. BÜKOOP'un yeni sosyal iş modelini sosyal girişimcilik ile hayata geçirirken ne amaçla ve hangi tür çalışmaları yaptıkları, bu çalışmaları nasıl yaptıkları, girişimin örgüt yapısı ve faaliyetleri örnek olay yöntemi kullanılarak incelenmiştir.

\section{Teorik Çerçeve}

Bu bölümde sosyal girişimcilik, sosyal inovasyon ve iş modelleri kavramlarına yer verilmiştir.

\section{a. Sosyal Girişimcilik}

Bir inovasyon ve deney alanı olarak görülen sosyal girişimcilik, girişimcilik disiplinine ve aynı zamanda daha geniş bir sosyal sektöre yeni bakış açıları kazandırma potansiyeline sahiptir. Sosyal girişimcilik, kurumsal sosyal sorumluluk ve kamu kurumları arasındaki arayüzler, sürdürülebilir kalkınmayı desteklemek için yeni işbirlikçi değer yaratma biçimlerini keşfetme konusunda büyük bir potansiyel sunmaktadır (Seelos ve Mair, 2005:245). Sosyal girişimcilik terimi, en önemli boyutları konusunda bir fikir birliğine varılamamasından dolayı tanımsal açıdan sorunlu bir terimdir ve yapılan tanımlar dar tanımlardan geniş tanımlara doğru çeşitlenmektedir. Dar anlamda, sosyal girişimciler genelde kâr amaçlı olmayan sektörlerde çalışmaktadır ve kaçınılmaz bir şekilde var olan programları adapte etmek yerine yeni programlar ve yeni çözümler ile ilgilidirler (Bielefeld, 2009: 71). Terim daha geniş olarak sosyal girişimciyi tanımlamaktadır. Buna göre sosyal girişimci, devletlerin, kâr amaçsız kuruluşların ve işletmelerin önemli sosyal süreçleri işaret edebilmeleri açısından neyi nasıl yapacakları ile ilgili kalıpları kıran fikirleri aracılığıyla sürdürülebilir, büyük ölçekli değişimleri hedefleyen bir birey, grup, ağ, örgüt veya örgütlerin ittifakıdır (Light, 2006: 50). Bu tanım temelinde sosyal girişimcilerin birey olmak zorunda olmadıkları, 


\section{Ç. Kaya 11/3 (2019) 1433-1449}

sürdürülebilir ve büyük ölçekli değişimi hedefledikleri, kalıpları kıran fikirler geliştirdikleri, tüm sektörlerde var olabildikleri, başarılı olmak için sosyal bir girişime bağlı olmaya ihtiyaç duymadıkları ifade edilebilir.

Sosyal girişimcilik, etkili bireyler ve kuruluşlar sosyal ihtiyaçların ele alınmasında devlet ve işletmelerin bıraktığı boşlukları doldurmak için çalıştığından dolayı gelişme içerisinde olan bir alandır (Bielefeld, 2008: 69; Dacin, Dacin ve Tracey, 2011: 1203). Tüm dünyada, sosyal açıdan bilinçli bireyler, daha önce işletmeler, hükümet ve sivil toplum tarafından göz ardı edilen sosyal sorunları ele almak için yenilikçi iş modelleri geliştirmiş ve uygulamıştır (Zahra v.d., 2009: 520). Bu akıma katkıda bulunan faktörler, çevresel ve sağlık krizleri ve kalıcı ekonomik eşitsizlik gibi talep tarafındaki faktörler ve küresel refah ve eğitimdeki artış gibi arz tarafındaki faktörlerdir (Nicholls ve Cho, 2006: 99). Buna paralel olarak, yönetim ve kâr amacı gütmeyen örgütlerle ilgili yazın, sürdürülebilirlik, yoksulluk ve sosyal eşitlik gibi sosyal kaygılar tarafından motive edilen girişimcilik faaliyetlerine giderek daha fazla odaklanmaktadır (Dacin, Dacin ve Tracey, 2011: 1204; Murphy ve Coombes 2009: 333). Her ne kadar bu yeni ortaya çıkan çalışma, sosyal girişimciliğin ve sosyal girişimcilerin değişen kavramsallaştırmaları tarafından bölünse de (bkz. Bielefeld, 2008), çoğu tanımda ortak bir faktör, sosyal sorunlara çözüm sağlayarak toplumsal değer yaratmanın birincil misyon oluşudur (Dacin, Dacin ve Tracey, 2011: 1204).

Bu noktada bazı yazarlar sosyal girişimcilik misyonunun ekonomik sonuçları dikkate almadığını, bazı yazarlar da ekonomik çıktıların sosyal girişimciliğin misyonunun bir parçası olduğunu öne sürmektedirler (Mair ve Marti, 2006: 36; Zahra vd., 2009), ancak yine de ekonomik misyonu birincil misyon olarak dikkate almamaktadırlar (Dacin, Dacin ve Tracey, 2011: 1205). Geleneksel girişimcilerin aksine, sosyal girişimciler ne önemli mali kâr elde etmeye organize olmakta ne de bunu beklemektedirler; bunun yerine, toplumsal sorunlara yenilikçi çözümler geliştirerek toplumsal fayda biçiminde değer yaratmayı amaçlamaktadırlar (Martin ve Osberg, 2007: 34). Bu misyon yeni girişimler yaratılarak veya mevcut örgütlerde yeniliklerle ele alınabilir (Heinze, Banaszak-Holl, ve Babiak, 2016: 316). Sosyal girişimcilik yeni girişimler yaratarak veya mevcut organizasyonları yenilikçi bir şekilde yöneterek sosyal zenginlikleri arttırmak konusunda fırsatları keşfetmek, tanımlamak ve kullanmak için yapılan faaliyetleri ve süreçleri kapsamaktadır. Zahra v.d (2009: 519), sosyal girişimcilerin, topluluklarına ve toplumlarına çeşitli düzeylerde önemli katkılar yaparak karmaşık ve kalıcı sosyal sorunlara yaratıcı çözümler sunmak için iş modelleri benimsediklerini ifade etmektedir. Dolayısıyla benimsenen bu iş modelleri ile sosyal girişimciler amaçlarını gerçekleştirebilecekleri faaliyet ve süreçleri tasarlamaktadırlar.

Heinze, Banaszak-Holl, ve Babiak (2016: 316), sosyal girişimcilik üzerine yapılan araştırmaların bireysel girişimciliğe ve tek başına "kahraman" aktörlere odaklandığını ifade etmektedirler. Bu çalışmaların toplumun yeniden canlandırılmasına yönelik vakıflar kuran başarılı bireysel girişimcilerin profillerini, sosyal girişimcilerin insan sermayesi becerilerini ve sosyal girişimcilerin bireysel özelliklerini tanımladığını vurgulamaktadırlar. Sosyal girişimciliğin grupları, ağları ve farklı sektörlerden kuruluşların ittifaklarını içerecek şekilde tanımları yapıldığına da dikkat çeken yazarlar, araştırmaların ABD'de oldukça başarılı olan ilk kâr amacı gütmeyen ilaç firması OneWorld Health Enstitüsü ve Bangladeş'te önde gelen mikro kredi bankası Grameen Bank gibi tek vakaların araştııılmasına odaklandığının altını çizmektedirler. Bu noktada Seelos ve Mair'in (2005: 241) "sosyal girişimcilik" terimi, mevcut pazarların ve kurumların tatmin edemediği temel insan ihtiyaçlarını etkin bir şekilde karşılamak için modeller yaratmış olan hızla artan sayıda kuruluşlara atıfta bulunmaktadır ve bu tanımlama Heinze, Banaszak-Holl, ve Babiak'ın (2016: 316) sosyal girişimci olarak kuruluşları çalışmalarına temel oluşturmaktadır.

Sosyal girişimcilik, geleneksel girişimciliğin kaynakları harekete geçirme becerikliliğini toplumu değiştirme misyonuyla birleştirmektedir. Yeni kaynak türlerini kullanmak ve bunları yeni yollarla birleştirmek için, sosyal girişimcilik, ilham veren değer yaratma modellerinin keşfedilmesi için zengin bir alanı oluşturmaktadır (Seelos ve Mair, 2005:242). Ayrıca sosyal girişimcilik, sorunları çözmek için yerel kapasiteleri inşa etmek ve kenara itilerek önemsizleştirilmiş grupların mevcut varlıklarını onların hayatlarını iyileştirmek için harekete geçirmek olarak da tanımlanmaktadır (Alvord, v.d., 2003: 144). Dolayısıyla başarılı sosyal girişimciler ekonomik, politik ve kültürel dönüşümünde kaldıraç kuvvetine sahip olabilmektedirler (Van Slyke ve Newman, 2006: 349).

Özelleştirme ve pazarlamaya yönelik küresel hareket, kâr amacı gütmeyen organizasyonları ve STK'ları da derinden etkileyerek sosyal hizmet sunumunda bırakılan boşlukları ele almaya zorlamıştır. Bu faaliyetler 
için geleneksel kaynaklardan sağlanan finansman azalmasına rağmen, bu programları sağlama maliyetleri artmıştır. Sonuç olarak, giderek daha fazla sayıda kâr amacı gütmeyen kuruluş genişleyen karmaşık sosyal ihtiyaçlara katılmış, ancak daha az fon kullanmışlardır. Bu da bazı kâr amacı gütmeyen kuruluşlara girişimcilik stratejileri ve yeni iş modelleri uygulamaları açısından yollar açmıştır. Bu yollar, sosyal misyonlarını devam ettiren programları finanse etmek ve işletmek için ortak ilişkiler kurmayı da içermektedir. Bu kurumsal değişiklikler ayrıca farklı türlerde sosyal girişimlere yol açmıştır (Zahra v.d., 2009: 520). Bu farklı türdeki sosyal girişimlerin rollerine yönelik olarak Montgomery, Dacin ve Dacin (2012: 375), kolektif sosyal girişimciliğe odaklanmışlardır. Kolektif sosyal girişimcilik, bireylerin önde gelen sosyal değişimlerdeki rolüne olan odağın ötesine giderek çoklu aktörlerin sosyal sorunları ele almak, yeni kurumlar oluşturmak ve eski kurumsal düzenlemeleri ortadan kaldırmak için ortaklaşa oynadıkları rolü ifade etmektedir. Kolektif sosyal girişimciler, sosyal iyilik için hareketler, ittifaklar ve pazarlar kurmak da dahil olmak üzere sosyal inovasyonlar yaparak ve sosyal iş modelleri geliştirerek çeşitli işbirlikçi faaliyetler yerine getirmektedirler.

\section{b. Sosyal İnovasyon ve Sosyal İş Modeli}

Girişimcilik, özellikle sosyal girişimcilik, sosyal inovasyon üzerine bir başka bakış açısı sunmaktadır. Daha spesifik olarak, bu açıdan sosyal inovasyon konusu, sosyal girişimciliğin sosyal inovasyon okulu tarafından ele alınmaktadır (Dees ve Anderson, 2006). Sosyal inovasyon okulu, girişimcileri yenilikçi olarak yorumlayan Joseph Schumpeter'in girişimcilik teorisine yoğun bir şekilde dayandığından, sosyal girişimciliği ve sosyal inovasyonu yakından ilişkili kavramlar olarak görmektedir. Bununla birlikte, bu yazın akımındaki sosyal inovasyon tanımlarına az rastlanmakta ve sosyal inovasyon sadece dolaylı olarak sosyal girişimcilerin yaptığı bir şey olarak ifade edilmektedir. Bu yazında sosyal inovasyon anlayışı, bir sosyal inovasyonun getirdiği olumlu sosyal değişimi vurgulamaktadır. Dolayısıyla, bu açıdan sosyal inovasyon, sosyal değişimin belirli bir ortamda gerçekleşmesine neden olan tüm karmaşık süreçle ilgilidir (Choi ve Majumdar, 2015: 12-13). Dees ve Anderson (2006: 44) sosyal girişimcilerin toplumsal değer üretme kalıplarını değiştirdiğini, kaynakları toplum için daha yüksek verime sahip alanlara kaydırdığını belirtmektedirler. Ayrıca, Martin ve Osberg (2007: 33), girişimciyi mevcut olanı çarpıcı bir şekilde kıran yeni bir çözüm geliştiren biri olarak tanımlayarak sosyal değişimin önemini vurgulamaktadır.

Taş ve Şemşek'e göre (2017: 484) sosyal girişimcilerin temel amacı sosyal değer ortaya çıkarmak ve sosyal iş modelleri, kâr odaklı iş, girişimcilik, kurumsal sosyal sorumluluk, hayırseverlik ve STK liderliği oluşturmaktır. Burada amaç sadece tek kullanımlık bir proje üretmek değil, aynı zamanda kararlı bir şekilde ileriye yönelik planlar yapmayı içermektedir ve eldeki kaynaklar sürekli büyüme ve gelişme için kullanılmaktadır. Sosyal girişimciler planladıkları alanda özel sektör ve kamu sektörü tarafından henüz doldurulmamış bir boşluğu aramakta olup, toplumun ihtiyaçlarını gözeten sosyal bir misyon sahibi kişi, grup ya da örgütlerdir. Schumpeter tarafından reformcu ve devrimci olarak betimlenen sosyal girişimcilerin yaptıkları iş yerel bile olsa küresel boyutta etki yapmaktadır. Sosyal girişimcileri diğer girişimcilerden ayıran en önemli unsur sosyal bir değer yaratmaktır. Sosyal bir değer yaratmaya çalışırken insanların problemlerini fark eden sosyal girişimciler kendileri için de bir fırsat yaratmış olmaktadırlar ve böylelikle yeni buluşlar ortaya koymaktadırlar.

Sosyal inovasyon ile ilgili bir başka tanım ise, sosyal inovasyonların sosyal değişim üreten yeni kombinasyonlar olmasıdır. Bu kombinasyon her biri kendisi inovasyon olan bir çok öğeden oluşmaktadır. $\mathrm{Bu}$ öğeler, işleri yapma yolları anlayışı, bu girişimin finanse edilmesi, yasal biçimleri, kuruluşu, üretim için kaynak edinme, üretimin yöntemi ve bunu bir işi yapmanın kabul görmüş yoluna dönüştürerek meşrulaştırmaktan oluşmaktadır (Swedberg, 2009: 102). Sosyal inovasyonlar yaratıcı yıkıma yol açmakta ve toplumun evrimine katkıda bulunmakta ve bu nedenle makro düzeyde değişime bir bağlantı sağlamaktadır (Choi ve Majumdar, 2015: 13).

Caulier-Grice vd. (2012: 18-21) sosyal inovasyonu aynı anda mevcut çözümlerden daha etkili bir şekilde bir sosyal ihtiyacı karşılayan ve yeni veya geliştirilmiş yeteneklere ve ilişkilere yol açan ve varlık ve kaynakların daha iyi kullanılmasını sağlayan ürünler, hizmetler, modeller, pazarlar, süreçler gibi yeni çözümler olarak tanımlamışlardır. Sosyal inovasyonlar hem toplum için iyidir hem de toplumun harekete geçme kapasitesini artırmaktadır. Bu tanımın ilk öğesi yeniliktir. Bu öğeye göre sosyal inovasyon alan, sektör, kullanıcı, bölge ve pazar için yenidir veya yeni şekillerde uygulanmaktadır. İkinci öğe ise sadece yeni fikrin var olmadığı 
aynı zamanda bu fikrin fiilen uygulandığı ve bu nedenle, sosyal inovasyonun sosyal icatlardan ayırt edilmesi gerektiğidir. Üçüncü öğe, etkinliktir ve sosyal inovasyonun diğer alternatif çözümlerden daha etkili olduğu anlamına gelir. Dördüncü öğe sosyal inovasyonun açıç̧a bir sosyal ihtiyacı karşılamak üzere tasarlanmasıdır. Bu tanımın beşinci ve son öğesi ise sosyal inovasyonların toplumun harekete geçme kapasitesini arttırmasıdır ve bu, yeni roller, ilişkiler, varlıklar ve yetenekler yaratarak ya da varlıkları ve kaynakları daha iyi kullanarak faydalanıcıları güçlendirdikleri anlamına gelmektedir. Bu tanım temelinde sosyal inovasyonun sosyal ihtiyacı karşılama amaçlı olarak yenilik yapmayı ve bu yeniliğin uygulama alanı bularak etkin olmayı içermekte olduğu ve sonuçta da toplumun harekete geçme kapasitesini arttırmakta olduğu söylenebilir.

Sosyal inovasyon çok geniş bir faaliyet yelpazesini tanımlamak için kullanılmaktadır. Sosyal inovasyon yeni ürün, hizmet ve programların geliştirilmesi; sosyal girişimcilik ve sosyal girişimlerin etkinliği; sosyal ilişkilerin ve güç yapılarının yeniden yapılandırılması; işyerinde yenilik; yerel ekonomik kalkınma için yeni modeller; toplumsal dönüşüm ve sistem değişimi; kâr amacı gütmeyen yönetim; ve işletme öncülüğünde sürdürülebilir kalkınmayı içermektedir. Sosyal inovasyonun tek, yaygın olarak kabul edilmiş bir tanımı olmaması sosyal inovasyonun ağırlıklı olarak akademik bir şekilde yansıtmak yerine, anlamların ve tanımların insanların bir şeyler yaparken yeni yollarla yapmasıyla ortaya çıktığı pratik bir alan olduğu gerçeğini yansıtmaktadır (Tepsie, 2014: 10).

Caulier-Grice vd. (2012: 18) sosyal inovasyonun yeni bir ürün, yeni hizmet, yeni süreç, yeni pazar, yeni platform, yeni organizasyon şekli veya yeni bir iş modeli olması temelinde bir sosyal inovasyonlar tipolojisi geliştirmişlerdir. Howaldt ve Schwarz (2010: 21) sosyal inovasyonu, mevcut uygulamalar temelinde mümkün olandan daha iyi bir şekilde sorunlara ve ihtiyaçlara cevap verme veya bunları tatmin etme amacıyla aktör grupları veya sadece belirli aktörler tarafından ele alınan belirli eylem alanlarındaki veya sosyal bağlamlardaki sosyal uygulamaların yeni bir birleşimi ya da düzenlemesi olarak tanımlamışlardır. Bunlara yeni hizmetler, yeni iş modelleri, web-tabanlı sosyal ağ örnek verilebilir. Benzer şekilde Choi ve Majumdar'a göre (2015: 28) sosyal inovasyon üç boyuttan oluşmaktadır. Birinci boyutu biçimselleştirme, ikinci boyutu değişim süreçleri, üçüncü boyutu ise sosyal sonuçlar elde etmektedir. Biçimselleştirme, yeni hizmet, yeni ürün, yeni teknoloji, yeni yasa, bir sosyal hareket, yeni bir iş modeli veya bunların kombinasyonu gibi sosyal inovasyonun değişik biçimlerini işaret etmektedir (çevre dostu ürünler, hizmetler, teknolojiler, uluslararası çalışma standartları, sosyal girişim fonlaması, kadınların güçlendirilmesi çalışmaları, işsiz veya düşük gelirli gruplara finansal destek gibi). Değişim süreçleri, sosyal uygulamaların, güç ilişkilerinin, sosyal yapıların ve sosyal ilişkilerin değiştirilmesini ifade etmektedir. Sosyal sonuçlar ise insan refahını ve çevresel refahını işaret etmektedir. Dolayısıyla sosyal girişimcilik insan ve çevresel refahı attırmak için sosyal değişikliklerin gerçekleştirileceği bir iş modeli oluşturmak olarak ifade edilebilir.

Burada bir iş modelinin, finansal olmaktan daha ziyade kavramsal bir iş modeli olduğunun altı çizilmelidir. Bir iş modeli bir işletmenin müşterilere nasıl değer yarattığını ve sunduğunu gösteren mantığı tanımlamaktadır (Teece, 2010: 173). İş modeli ayrıca bir işletmenin müşterilerine değer önerisini, gelirini ve değer ağını kombine etmektedir (Zott v.d., 2011). Bir iş modeli bir örgütün nasıl değer yarattığı, bu değeri nasıl ilettiği ve elinde tuttuğu mantığını tanımlamaktadır (Osterwalder ve Pigneur, 2010:14). Sosyal iş modeli ise klasik iş modellerinden farklıdır ve sosyal bir değerin ölçülebilir bir şekilde nasıl yaratılacağını gösteren bir yol haritasıdır (The Social Business Model, 2015: 10). Sosyal iş modelleri ve sosyal girişimler toplumda sürdürülebilir gelişimi ve kalkınmayı sağlayan ve giderek gelişen alanlardır (Taş ve Şemşek, 2017: 495).

\section{Yöntem}

$\mathrm{Bu}$ çalı̧̧mada sosyal bir inovasyon olarak sosyal iş modellerini hayata geçiren bir sosyal girişimci olan Boğaziçi Üniversitesi Tüketim Kooperatifi (BÜKOOP) incelenmiştir. Öncelikle çalışmanın yöntemi sunulmuş, ardından BÜKOOP'un ortaya çıkış bağlamı aktarılarak çalışmanın bulguları olan BÜKOOP'un sosyal girişimcilik çerçevesinde tüketici kooperatifi modelini oluşturma çalışmaları ve BÜKOOP sosyal iş modeline yer verilmiştir.

Bir sosyal olguyu derinlemesine anlayabilmek için örnek olaydan yararlanmak literatürde tercih edilen bir yaklaşımdır (Yin, 2009). Nitel veri bu noktada çalışmanın gerçekleştirilmesi için en uygun olan veri türüdür zira karmaşık sosyal süreçlerin anlaşılmasında anlamlı ve yeni bakış açları sağlayabilmektedir (Eisenhardt 
ve Graebner, 2007). Bu nedenle bu çalışmada örnek olay yöntemi kullanılmış olup, ikincil veri kaynaklarından (Kaynakça'da yer verilmiştir) yararlanılmıştır. BÜKOOP hakkında çıkan haberler, yapılan mülakatlar, yazılan bilimsel makaleler, BÜKOOP web sitesinde yer alan bilgilerden yararlanılarak bu sosyal girişimin nasıl ve ne amaçla başlatıldığı, hayata geçirirken hangi tür çalışmaların yapıldığı, bu çalışmaların nasıl yapıldığı, girişimin örgüt yapısı ve faaliyetleri ortaya konmaya çalışılmıştır. Bu yapılırken Tracey, Phillips ve Jarvis'in (2011) kurumsal girişimcilerin yeni bir örgüt formu oluşturmaları sırasında yapmış oldukları çalışmalara odaklanarak geliştirdikleri modelden yararlanılmıştır. Ayrıca Sosyal İş Modeli Kanvas'ından (Kent State University, 2019) ve Osterwalder ve Pigneur'un (2010) iş modeli kanvasından yararlanarak BÜKOOP sosyal iş modeli elde edilen veriler çerçevesinde açılanmaya çalışılmıştır.

BÜKOOP'un bu araştırma için seçilmesinin nedeni tüketici kooperatifi iş modelini ilk kez uygulayan ve gida alışverişi alanında aracı olmaksızın küçük üreticileri ve tüketicileri buluşturarak eşsiz bir alternatif sosyal iş modeli biçimlendiren ve farklı örgütlenme biçimleri sergileyen bir kooperatif olmasıdır.

\section{Bulgular}

Bu bölümde Boğaziçi Üniversitesi Tüketim Kooperatifi (BÜKOOP) örnek olay incelemesinin bulgularına yer verilmiştir.

\section{a. Tüketici Kooperatifleri ve BÜKOOP'un Ortaya Çıkışı}

Dünyada çiftçilik yapanların çoğu kendi aile bireyleriyle çalışmakta ve küçük aile çiftçileri olarak anılmaktadırlar. Türkiye'deki çiftçilerin \%85'i küçük aile çiftçileridir. Geri kalanı ise tarımsal işletme sahiplerinden oluşmaktadır. Köylerde yaşayan küçük aile çiftçileri küçük ölçekte üretim yapmaktadırlar. Kooperatifler küçük ölçekte üretim yapan köylüler için bir temel savunma mekanizmasıdır (Aysu, 2014). Kooperatifler 1163 sayılı yasa hükümlerine göre kurulmuştur. Tüzel kişiliği haiz olmak üzere ortaklarının belirli ekonomik menfaatlerini ve özellikle meslek veya geçimlerine ait ihtiyaçlarını işgücü ve parasal katkılarıyla karşılıklı yardım, dayanışma ve kefalet suretiyle sağlayıp korumak amacıyla gerçek ve tüzel kişiler tarafından kurulan değişir ortaklı ve değişir sermayeli ortaklıklardır (1163 sayılı Kooperatifler Kanunu, m.1). Aysu (2014), küçük ölçekli üretim yapan köylülerin bir araya gelerek kendilerini ve üretimlerini büyük toprak sahiplerinin yanı sıra tüccar ve sanayiciye karşı güçlerini birleştirerek, kooperatifleri kurarak koruyabileceklerini ifade etmektedir.

Kâr amacı taşımayan kooperatifler, vakıflar, dernekler, sendikalar ve meslek kuruluşları genel olarak Sivil Toplum Kuruluşları (STK'lar) adı altında toplanmaktadır. Sivil toplum ya da devlet-dışı örgütler, belirli bir takım amaçları gerçekleştirmek isteyen insanları birleştiren, kamunun gerçekleştirmediği ve ihtiyaç duyulan çalışmaları yapan, kendi üyelerine hizmet eden, devletten bağımsız ancak işbirliği içindeki kâr amacı taşımayan kurumlardır. Temelde aynı amaç doğrultusunda ve aynı fikre sahip kişilerin birleşmesi ve amaçlarını gerçekleştirmesi felsefesindedir (Saruhan, 2017:2). Sivil Toplum Kuruluşları (STK'lar) terimi çoğunlukla, tamamı veya büyük bir kısmı hükümetten bağımsız olarak hareket eden ve temel amacı ticari çıarlardan ziyade, insancıl ve işbirliğine yönelik faaliyette bulunmak olan kuruluşları ifade etmek için kullanılmaktadır (Atayeter, Özilhan ve Aslan, 2004: 28). Sivil Toplum Kuruluşları'nın (STK'lar) bir diğer tanımı ise gönüllülük boyutunun altını çizmekte ve STK'ların toplumda insani yaşamı ilgilendiren tüm alanları ve kültürel, siyasi ve iktisadi konuları kapsayan bazı norm ve kuralların yerleşmesini sağlamak amacıyla gönüllülük temelinde oluştuğunu ifade etmektedir (Çetin, 2005:1).

Genel anlamda Sivil Toplum Kuruluşları (STK'lar), "eşitliği yaygınlaştırmak, toplumsal sorunları belirlemek, kaynak temin etmek, insanlığın onurunu yükseltmek, kamu eğitimi, hayırseverlik ve sosyal hizmetler sağlamak, örgütlenmeyi teşvik etmek ve demokratik ilke ve kurumların güçlendirilmesini sağlamak" gibi konularda çalı̧̧maktadırlar (Güloğlu ve Es, 2006:150). Ancak Aysu'ya göre (2014) kooperatifler zaman içerisinde tarımsal kooperatiflerdeki yasal değişikliklerle (tarım reformu vb.) birlikte varsayılan görevlerini yerine getirememeye başlamışlardır. Üretimden pazarlamaya şirketlerin daha fazla egemen olacağı bir ortamın oluşmasına neden olan bu değişimler küçük üreticileri zor durumda bırakmıştır ve bu sorunlar farklı tüketici kooperatifi modellerinin oluşmasına zemin hazırlamıştır. Çünkü bu modeller şirketlere karşı alternatif olan modellerdir ve böylelikle çeşitli güçleri bir araya getirerek topluluk olarak önemli işlevler üstlenebilmektedirler. Kooperatifler, yerel kültürün yerleştirilip yaşamın yerelleşmesinde önemli bir paya sahiplerdir. Kooperatifler kredi verip, mal satabilirler, tüm üyeler faaliyetlerden eşit derecede sorumludur 
ve herkesin eşit oyu vardır. Kararlar ortak alınarak kolektif bir liderlik gerçekleştirilmelidir (Aysu, 2014). Benzer şekilde de Rooij, Özgüzel ve Bilgin (2017: 814) tarımsal üretimin gerek ekonomik ve sosyal açıdan, gerekse teknoloji kullanımı ve ekolojik sürdürülebilirlik açısından performansın sağlanmasındaki en önemli etkenlerden birisinin üreticilerin örgütlü olması gerektiğini ifade etmişlerdir. Bu konuda, kooperatif örgütlenme en basit ve en uygun ve en yararlı bir örgütlenme modeli olmaktadır. Böylece, kooperatifleşen tarım üreticileri gerek tarımsal girdilerin elde edilmesi açısından, gerekse üretim ve ürün pazarlaması açısından önemli imkânlara kavuşmaktadırlar. Tarımsal üretim alanında giderek önemini artıran “Organik Tarım" sektöründe kooperatifçiliğin yeri ve önemi büyüktür.

Aysu'ya göre (2014) ucuz kimyasallar kullanılmasının önüne geçmek ve endüstriyel gıda katkılar kullanılmasının karşısında direnç göstermek kooperatiflerin sorumluluğudur ve hem üretici kooperatiflerinin hem de tüketici kooperatiflerinin bu noktada buluşturulması ve aracısız bir biçimde ürünlerin ulaştırılması önem arz etmektedir. Organik tarım temaslı ve temassız olmak üzere iki şekilde yapılmaktadır. Temaslı yöntem üreticiden tüketiciye aracısız olarak ürünlerin ulaştırılmasıdır. Temassız sistem ise sertifikalı organik tarım yapan büyük gıda üreticilerinin aracılar aracılığıyla ürünlerin tüketiciye ulaştırılması anlamına gelmektedir. Sertifika şirketleri burada üretici ve şirket arasında yerini almakta, üreticiler bu şirketlerin belirttiği organik gübre, ilaç ve tohumları almakta, ürünleri de pazara gıda şirketleri sunmaktadır. Dolayısıyla organik ürünler tüketiciye yüksek fiyatlarla sunulmaktadır. Katılımcı garantili (temaslı) sistemlerde ise şirketler temin ve pazarlamada devre dışı bırakılmakta, hiyerarşik olmamakta, katılımcı ve kolektif bir hareketin aracı olmaktadır. Bu sistemde üretim yapan çiftçiler, üretim sürecinde sentetik gübre, kimyasal böcek ilaçları, hibrit ve GDO'lu tohumları kullanmamaktadır.

Bu sistemde ekolojinin korunması amaçlı ekolojik bir tarım yaklaşım zorunlu olduğundan çiftçiler sağlıklı ürün üretmekte ve ürünlerin kullanıcıları bu sağlıklı ürünlerle beslenmektedir. Ekolojik ürün talep eden kullanıcılara güvenebilecekleri ürünleri sunmak bu sistemin organik sertifikasyon sistemleriyle yegâne ortak noktasıdır, zira katılımcı garantili sistemler güvenilir bir sertifikasyon sistemi olmanın çok daha ötesine geçmekte olup başka bir ekolojik bir yaşamın hasıl olmasında bir araç görevi görmektedir. Katılımcı Garanti Sistemleri inisiyatifleri günümüzde binlerce küçük organik çiftçiye ve kullanıcıya hizmet vermekte olup sayıları her geçen sene artmaktadır. Küçük ölçekli üretim yapan köylüler ise geçimlerini emekleri karşılığında ücret olarak değil ürettiklerini satarak sağlamaktadırlar. Bu ise özgürlük ve bağımsızlığı beraberinde getirmektedir. Katılımcı garanti sistemlerinde prensipler katılımcılar tarafından kolektif olarak belirlenmektedir. Bu sistemler çoğulcudur ve hiyerarşik bir yapıya izin vermemektedir. Çiftçiler ve yarı üreticiler sisteme doğrudan katılmakta, bilgi ve deneyimlerini paylaşmaktadırlar. Çiftçi ve kullanıcılar süreçleri birlikte belirlemektedir, ilişkiler şeffaftır, katılımcılar tarla ziyaretleri yapabilmekte, hakemliklerde yer alabilmektedirler. BÜKOOP böyle bir sistem temelinde kurulmuş bir tüketici kooperatifidir (Aysu, 2014).

\section{b. Sosyal Girişimcilik ve BÜKOOP Modeli}

Boğaziçi Mensupları Tüketim Kooperatifi (BÜKOOP), “Boğaziçi Üniversitesi Kuzey Kampüs'te küçük üreticiden tüketiciye aracısız olarak, sağlıklı, adil gıdayı, uygun fiyatla ulaştırmayı hedefleyen bir tüketim kooperatifi" olarak 2009 yılında kurulmuştur. Kâr amacı gütmemekte ve sadece gönüllü emeğiyle organize olmaktadır. Baraka adı verilen satış alanında hafta içi her gün 13:00-13:30 ve 17:00-17:30 arasında gönüllü nöbetçilerle faaliyet gösterilmektedir. Her ayın ilk cumartesi günü ise Uzun Cumartesi etkinliğinde BÜKOOP Baraka 11:30-14:30 arası faaliyet göstermektedir. BÜKOOP Baraka ürün satışının ve depolamasının yapıldığı bir alandır. Burada aynı zamanda tüketiciler ile üreticiler arasında bilginin ilk elden paylaşılmaktadır. Tüketicilerin ürünler ve üretim süreçleriyle ilgili sordukları soruların tüm katılımcılarla kolektif bir şekilde cevaplarının arandığı kamusal bir yerdir. Bu bilgi paylaşımı sırasında amaçlanan mahallelerde ve iş yerlerinde BÜKOOP'a benzer olan tüketim kooperatifi modellerinin oluşturulmasına yönelik kişilerde ilgi uyandırmaktır. Yeni tüketim kooperatiflerinin kurulması ise tüketicilerin ve küçük üreticilerin tarım ve hayvancılık alanında deneyimlediği sorunlara çözümler sağlayabilecektir. Ayrıca organik sertifikalı ürünleri genelde yüksek gelir grupları satın aldıkları için, sağlıklı ve kimyasal madde ihtiva etmeyen gıdaya düşük gelir gruplarının da ulaşabilmesini sağlamak bir diğer amaçtır. Ek olarak tarlaları ziyaret edilmesi, küçük üreticilerle toplantılar ve söyleşiler yapılması ve üretici-tüketici arasındaki ilişkilerin uzun dönemli ve güvene dayalı olmasını sağlamak için de çalışmaktadırlar (BÜKOOP, 2014). BÜKOOP, Boğaziçi Üniversitesi mensuplarının kurduğu bir tüketim kooperatifidir. Üniversitedeki paydaşlar 2009 yılında bir araya gelmişler ve yukarıda bahsedilen çalışmaların gerçekleştirilebilmesi için 
daha demokratik, şeffaf ve organize işleyecek bir model olarak tüketim kooperatifi modelini seçmişlerdir. BÜKOOP ortak sayısı 200 olup, kooperatife üye olmayan BÜKOOP tüketicileri ile toplulukta toplamda 400500 kişi bulunabilmektedir. Topluluğun iletişimde olduğu üretici sayısı ise 20 civarındadır (BÜKOOP, 2016).

En önemli ölçüt STK'ların esasları olan katılımclık, şeffaflık, gönüllülük esası, demokratik yönetim çerçevesinde işlerin yürütülmesidir. Demokratik yönetim çerçevesinde örneğin gönüllülerin alınacak kararlarda birbirlerini ikna etmeleri gerekmektedir. Ayrıca BÜKOOP toplantıları herkese açık olarak yapılmaktadır. BÜKOOP’ta gönüllüler ve üretici / tüketici açısından cinsiyet ağırlıklarının eşit olmasına, belirli işlerin gönüllüler arasında sadece kadınlar ya da sadece erkekler tarafından yapılmamasına dikkat edilmektedir. Kadın üreticilerin tüm üreticiler arasında önemli bir varlığı ve yeri vardır. Her yıl yaklaşık olarak 20-25 gönüllü, nöbet zamanlarında BÜKOOP'ta ürünlerin sorumluluğu, temizlik işleri (BÜKOOP tarafından temizlik şenliği olarak ifade edilmektedir), paketleme çalışmaları, ürün satışı ve muhasebe hesabı tutma gibi çeşitli faaliyetlerde rol almaktadırlar. Mali müşavir hariç ücretli çalışan olmayıp, haftada en az 3-4 saatlerini BÜKOOP'a ayıran gönüllüler tarafından bütün işler organize edilmektedir. Bahsedilen bütün bu faaliyetler ve üstlenilen görevler içinde bulunulan sene için paylaşılmaktadır. Gönüllüler tüm operasyonel ve stratejik kararları topluluğun e-posta grubunda yazışarak ya da haftalık toplantılarda oybirliği ile almaktadır. Birbirlerini ikna etmek ve hiç kimsenin alınan karar konusunda endişesi kalmayana kadar tartışmak büyük önem arz etmektedir. Bu tarz hiyerarşik olmayan demokratik bir yapının şüphesiz zaman zaman çok hızlı karar veremediği de olmakta, ancak bu durum üreticilere ve BÜKOOP mensuplarına anlatılmaya çalışılmaktadır (BÜKOOP, 2016).

\section{i. BÜKOOP'un Sosyal Girişimcilik Çerçevesinde Tüketici Kooperatifi Modelini Oluşturma Çalışmaları}

Tracey, Phillips ve Jarvis (2011) bir sosyal girişimde kurumsal girişimcilerin yeni bir örgüt formu oluşturmaları sırasında yapmış oldukları çalışmalara odaklanarak bir model geliştirmişlerdir. Bu modelde girişimcilerin yaptıkları işleri üç teorik boyutta toplamışlar ve bu boyutların alt boyutlarını sunmuşlardır. Bu üç teorik boyut ve alt boyutları şu şekilde ifade edilmektedir (s. 64):

1. Mikrokurumsal iş: Fırsatları tanımlama

a. Problemin çerçevesini sunma

i. Mevcut kurumların sorunların kök nedenini ele almaması

ii. Sosyal problemin başka bir sosyal probleme bağlı olması (işsizliğe bağlı evsizlik gibi)

b. Olgulara ters düşen düşünme biçimi

i. Bir girişimin sosyal bir probleme sahip insanları dışlaması yerine onların topluma katkıda bulunmalarını sağlamaya çalışmak

ii. Sosyal problemin bağlı olduğu başka bir sosyal problemin çözülmesinin o problemin çözümüne de katkıda bulunacağını düşünmeleri (evsizlerin istihdam edilmeleriyle birlikte bunun kendi yaşamlarını iyileştirmeleri için bir motivasyon kaynağı olabileceği gibi)

2. Mezokurumsal iş: Yeni örgütsel formu tasarlama

a. Örgütsel şablonu inşa etme

i. Sadece sosyal bir getiri mi yoksa ayn zamanda finansal getirinin de hedeflenip hedeflenmediği

ii. Girişime bağlı olan kişilerin yaşamlarını sürdürebilmeleri için dengeli ve istikrarlı bir gelire ihtiyaç duyması

b. Örgütsel şablonu kuramsallaştırma

i. Elde edilen fazla kazancın nasıl tekrar sosyal çalışmalara dönüştürüleceği ile ilgili bir sistem kurma

ii. İhtiyacı olanlara yardım yapmaktan ziyade iş vererek onların yaşamlarını devam ettirmelerine destek olmak

3. Makrokurumsal iş: Yeni örgütsel formu meşrulaştırma

a. Makro düzeyde bir söylem ile bağlama

i. Girişimi sosyal girişim hareketinin bir parçası haline getirme çalışmaları

ii. Girişimin kamu yararı için iş yapmanın yeni bir yolunu temsil etmesi

b. Son derece meşru aktörlerle uyum sağlamak

i. Kamu destek beyanları 
ii. Sosyal girişimlerle ilgili hükümet politikalarının şekillenmesini sağlamaya yardımcı olmak

Tracey, Phillips ve Jarvis'in (2011:64-65) bu modelini temel alarak, elde edilen verilerin analizi ile BÜKOOP'un yeni bir iş modeli olan tüketim kooperatifini oluştururken ne tür sosyal girişimcilik çalışmaları yaptıkları ortaya konulmaya çalışılmıştır. Buna göre;

\section{Mikrokurumsal iş: Fırsatları tanımlama}

\section{a. Problemin çerçevesini sunma}

i. Mevcut kurumların sorunların kök nedenini ele almaması: Tarımda ucuz kimyasallar kullanımının önüne geçmek, endüstriyel gıda katkıları kullanılmasının karşısında direnç göstermek, sertifikalı organik tarım yapan büyük gıda üreticilerinin yüksek fiyatla ürün sunmaları, ve küçük üreticileri koruma gerekliliği, var olan kooperatiflerce ele alınmayıp tüketicilerin yaşadıkları sorunlara çözüm bulma konusunda yetersiz kalmaları ve büyük şirketlere karşı alternatif üretememesi yeni bir modelin düşünülmesinin önünü açmıştır (Aysu, 2014). BÜKOOP bir sosyal girişimci olarak "hükümetlerin, kurumların ve işletmelerin yapamayacağı sosyal ihtiyaçları ele alan mal ve hizmetler sağlamak için alternatif yapılar inşa etmek ve işletmektedir" (Zahra v.d., 2009: 523).

ii. Sosyal problemin başka bir sosyal probleme bağlı olması: Sertifikalı organik tarım yapan büyük gıda üreticilerinin yüksek fiyatla ürün sunmaları tüketiciyi zor durumda bırakmakta ve organik gidaya ulaşmak zorlaşmaktadır. Tüketiciler gıda katkı maddeli, pestisitle ilaçlanmış sağlığa zarar verecek gıdalarla baş başa kalmışlardır. Bu da sağlık problemlerine neden olmaktadır. Ayrıca küçük ölçekli üretim yapan çiftçiler desteklenmemekte, üretimlerinde ve satışlarında sorunlar yaşamakta ve sertifikalı organik üretim yapan büyük şirketlere alternatif olan bir üretim söz konusu olmamaktadır.

\section{b. Olgulara ters düşen düşünme biçimi}

i. Bir girişimin sosyal bir probleme sahip insanları dışlaması yerine onların topluma katkıda bulunmalarını sağlamaya çalışmak: BÜKOOP organik ve küçük ölçekte üretim yapan çiftçilerin ve üreticilerin emek karşılığında ücret alarak değil, bunun yerine ürettiklerini satarak geçimlerini sağlayabilmeleri ve tüketicilerin de organik ürünlere daha uygun fiyatlarla ulaşmasını sağlayabilmek adına bir girişim başlatmıştır (Aysu, 2014).

ii. Sosyal problemin bağlı olduğu başka bir sosyal problemin çözülmesinin o problemin çözümüne de katkıda bulunacağını düşünmeleri: Küçük üreticilerin desteklenmesi ve katılımcı bir şekilde sisteme dahil edilmeleri hiyerarşik yapıya sahip olmayan bu kooperatifte çiftçilerin ve yarı üreticilerin sisteme doğrudan katılmalarını, bilgi ve deneyimlerini paylaşmalarını sağlamıştır. Böylece çiftçi ve kullanıcılar süreçleri birlikte belirlemekte, ilişkiler şeffaf olmakta, katılımcılar tarla ziyaretleri yapabilmekte, hakemliklerde yer alabilmektedirler (Aysu, 2014). Yeni tüketim kooperatiflerinin kurulmasına da öncülük ederek, hem tüketicilerin hem de küçük üreticilerin gıda, hayvancılık ve tarımdaki sorunlarına çözümler sunmaya çalışılmaktadır. Yüksek gelirli grupların organik gıda tüketmesi anlayışını sorgulayarak, tüm gelir gruplarının sağlıklı gıdaya erişebilmesini sağlamak ve üreticilerle hem söyleşiler yaparak hem de tarla ziyaretleri yaparak üretici ve tüketici ilişkilerinin uzun dönemli olabilmesi ve güven temelinde olabilmesi için çalışmaktadır (BÜKOOP, 2014).

Aracısız ürün ağı yöntemleriyle ürün pazarlama ya da dağıtımının tüketiciler için olduğu kadar üreticiler açısından da önemli etkileri bulunmaktadır. Ürün arz 


$$
\text { Ç. Kaya 11/3 (2019) 1433-1449 }
$$

zincirinin kısalması ile en başta ürünlerde oluşabilecek kayıp ve israfların önüne geçilmekte, üreticiler ürünlerini daha taze olarak satabilmektedir. Bu ağlar sayesinde üreticiler, daha istikrarlı ve piyasa fiyatına ya da biraz altına satış gerçekleştirdikleri için daha yüksek gelir elde etmektedirler. Ayrıca riskin paylaşılması ve üretim için planlamaya yönelik bilgilere sahip olunması gibi özellikler üretim ve üreticiyi korumaktadır (Çelik, 2006: 31).

\section{Mezokurumsal iş: Yeni örgütsel formu tasarlama}

\section{a. Örgütsel şablonu inşa etme}

i. Sadece sosyal bir getiri mi yoksa aynı zamanda finansal getirinin de hedeflenip hedeflenmediği: BÜKOOP, Boğaziçi Üniversitesi Kuzey Kampüs'te sağlıklı ve adil gıdayı aracısız olarak uygun fiyatla küçük üreticiden tüketiciye ulaştırmayı hedefleyen bir tüketim kooperatifi olarak 2009 yılında kurulmuştur. Kâr amacı gütmeyen ve sadece gönüllü emeğiyle organize olan bir yapıya sahiptir (BÜKOOP, 2014).

ii. Girişime bağlı olan kişilerin yaşamlarını sürdürebilmeleri için dengeli ve istikrarlı bir gelire ihtiyaç duyması: BÜKOOP üreticilerinin üretimlere devam edebilmesi ve ayakta kalabilmeleri için onlarla uzun soluklu ilişkiler kurmaktadır. (BÜKOOP, 2014). Yine yerel pazarlarda tarhana, salça gibi ürünler üreterek satan kadın derneklerinin ürettiği ürünler tüketiciye sunularak bu dernekler desteklenmektedir.

\section{b. Örgütsel şablonu kuramsallaştırma}

i. Elde edilen fazla kazancın nasıl tekrar sosyal çalışmalara dönüştürüleceği ile ilgili bir sistem kurma: Gelir fazlası elde edilirse, bunun büyüme yerine ürün çeşitliliğini arttırma ve çeşitli toplumsal sorunlarda kullanmak üzere değerlendirilmesi planlanmaktadır. Sadece satış amaçlı bir kooperatif olmadığından, BÜKOOP bilgi üretimi ve paylaşımını da destekleyerek, kendilerinden yardım ve destek isteyen diğer girişimlere kooperatifin nasıl kurulacağı, nasıl işleyeceği hakkındaki uygulama deneyimlerini kitapçık bastırarak paylaşmayı da planlamaktadırlar (Taşyürek, 2019). Gelecekte gönüllü iş gücü yeterli olduğunda ise bilinirliği arttırmak amaçlı olarak ürünlerin e-ticaret yöntemiyle satışını sağlamak da hedeflenmektedir (BÜKOOP, 2016).

ii. İhtiyacı olanlara yardım yapmaktan ziyade iş vererek onların yaşamlarını devam ettirmelerine destek olmak: Sağlıklı ve ekolojik ürünlerin tüketiminin yalnızca yüksek gelir sınıflarının tekelinde olmadığı ve ayrıca geleneksel tarım yöntemleriyle üretilip organik sertifikalı ürünler haline gelip, bu ürünlerin butik organik mağazalarda satışının yapılmasıyla sağlıklı ürün tüketiminin seçkinleştirilmemesi gerektiği ve doğal koşullarda yetişen ürünlere herkesin erişimin bir hak olduğu anlayışıyla faaliyet gösterilmektedir. Üretici ve tüketici arasında aracıların varlığıyla üretici ve tüketicilerin ayrıştığı tüketim sistemine alternatif olarak, aracıları devre dışı bırakıldığı ve bireysel üreticilerle, köy ve kadın kooperatifleriyle beraber çalışılan bir sistem kurulmaya çalışılmıştır. Dolayısıyla beslenme hakkının sadece yeterli miktarda gıdaya erişmek anlamına gelmediği, tüketilen besin içeriği ile ilgili tüketicilerin bilgi sahibi olması ve güvenli ve sağlıklı gıdaya ulaşması hakkını da kapsadığı ifade edilmektedir (Dallı, 2015).

3. Makrokurumsal iş: Yeni örgütsel formu meşrulaştırma

a. Makro düzeyde bir söylem ile bağlama

i. Girişimi sosyal girişim hareketinin bir parçası haline getirme çalışmaları: BÜKOOP'un satış mekânı, satış ve dağıtımın yapıldığı kadar, bilginin paylaşıldığı, tüketicinin hem gönüllülere hem de üreticiye doğrudan sorularını sorabildiği, bir 


$$
\text { Ç. Kaya 11/3 (2019) 1433-1449 }
$$

ürünü tadabildiği ya da ürün hakkında kaygılarını veya övgülerini dile getirebildiği bir sosyal kamusal mekândır (BÜKOOP, 2016). Bilgi üretimi ve paylaşımını da destekleyerek, diğer girişimlere kooperatifin nasıl kurulacağı, nasıl işleyeceği hakkındaki uygulama deneyimlerini kitapçı bastırarak paylaşmayı da planlamaktadırlar (Taşyürek, 2019).

İsyerlerinde, mahallelerde daha fazla sayıda tüketim kooperatifinin kurulması, gönüllülük anlayışıyla çalışılması ve daha çok insana ihtiyaç temelinde gıda egemenliği ideallerinin aktarılması gerekliliğinin altı çizilmektedir. Gıda alanında faaliyet gösteren STK'ların, üreticilere altyapı desteği veren projeler yapması önemli görülmektedir. Depolama gibi altyapı eksiklikleri, fiyatlandırmaya dair sorunlar, paketleme ve kargolamaya dair problemler, ticari ve hukuki bilginin eksikliği üreticilerde görülen en önemli sorunlardan olup bu eksikliklerin giderilmesi için aracısız gıda ağı ve topluluklarının gelişmesi ve yaygınlaşması gerektiği ifade edilmektedir. Bunların çözümü de bilginin sistematik olarak üretilmesi ve yayılması olarak görülmektedir. Bilinirlik yükselten kampanyalara verilen fonlar kadar, üreticilere altyapı sağlayabilecek fonların da geliştirilmesi ve dağıtılması gerekmektedir. BÜKOOP'a göre, üreticilere STK'lar tarafından çeşitli ulusal veya uluslararası projelere ve fonlara başvurabilmeleri için ücretsiz ve karşılıksız danışmanlık hizmeti sağlanması da pek çok yeni küçük üreticinin üretime devam etmesini sağlayabilecektir (BÜKOOP, 2016).

ii. Girişimin kamu yararı için iş yapmanın yeni bir yolunu temsil etmesi: BÜKOOP, küçük üreticilerden tüketicilere sağlıklı ve katkı maddesiz gıdayı aracısız bir şekilde uygun fiyatta ulaştırma çalışmaların gerçekleştirilebilmesi için daha demokratik, şeffaf ve daha iyi organize işleyecek bir kurum olarak tüketim kooperatifi modelini seçmiştir. Kooperatif modeli şeffaflık ve demokratik yönetimi öne çıkaran, ortaklarına daha kolay hesap verebilen bir model olması sebebiyle tercih edilmiştir (BÜKOOP, 2016).

\section{b. Son derece meşru aktörlerle uyum sağlamak}

i. Kamu destek beyanları: Çiftçi-Sen Genel Başkanı gerek gazetecilerle yaptığı röportajlarda gerekse de sendikanın internet sitesinde yayınlanan mülakatlarda ve BÜKOOP'un internet sitesindeki yazılarıyla BÜKOOP çalışmalarına ve BÜKOOP sonrası sayıları artmaya başlayan diğer tüketici kooperatiflerine destek vermektedir (Cumhuriyet Gazetesi, 2018). Ayrıca BÜKOOP’un Boğaziçi Üniversitesi mensupları tarafından kurulmuş olması ve bu nedenle Boğaziçi Üniversitesi'nin meşruluğu ve bilinirliğinin kooperatifin başarısı, meşruiyeti ve bilinirliği açısından büyük önem arz etmektedir.

ii. Sosyal girişimlerle ilgili hükümet politikalarının şekillenmesini sağlamaya yardımcı olmak: Ulusal alanda tarım ve gıda politikalarının belirlenmesinde ve çiftçilerin haklarının aranmasında aktif rol oynayan çifţi sendikalarının, derneklerinin, BÜKOOP gibi daha yerel bir alternatif ekonomik ve sosyal bir üreticitüketici ağını hayata geçiren örgütlenmelerle ilişkilenmesi ve ortak tabanda mücadele etmesini sağlayacak alan açılması gerekliliğinin altı çizilmiştir (Kurtiç, 2014). Bu ortak girişimler ve çalışmalar hükümet gıda ve tarım politikalarının şekillenmesinde aktif olarak rol almaya yol açabilir.

Yasalar, düzenlemeler, politik kabul edilebilirlik, verimsizlikler ve / veya eksiklikler mevcut hükümet ve iş kuruluşlarının birçok önemli sosyal ihtiyacı etkili bir şekilde ele almasının önüne geçeceği için sosyal girişimcilik önemli görülmektedir (Zahra v.d., 2009: 523).

\section{ii. BÜKOOP Sosyal İş Modeli}


Bu bölümde Kent State University'nin 10 temel taşlı Sosyal İş Modeli Kanvas'ından (bkz. Kent State University, 2019) ve Osterwalder ve Pigneur'un (2010) dokuz temel taşlı iş modeli kanvasından yararlanarak BÜKOOP sosyal iş modeli elde edilen veriler çerçevesinde açıklanmaya çalışılmıştır.

Ana Kaynaklar: Üyelerin kooperatife ortak olurken yaptıkları ödemeler ve ürün satışları finansal kaynakları oluşturmaktadır. İnsan kaynağını ise kooperatif ortakları ve gönüllüler oluşturmaktadır. Faaliyetlerin gerçekleştirilmesi için gerekli olan kaynaklardan bir diğeri de üreticilerdir.

Ortaklar ve ana paydaşlar: Bu sosyal iş modelindeki amaçlanan faaliyetlerin gerçekleştirilmesi için tedarikçi ve ortaklar ağını küçük üreticiler ve kooperatif ortakları oluşturmakta, gönüllülerle desteklenmektedir. BÜKOOP ortak sayısı 200 olup, kooperatife üye olmayan BÜKOOP tüketicileri ile toplulukta toplamda 400500 kişi bulunabilmektedir. Topluluğun iletişimde olduğu üretici sayısı ise 20 civarındadır. Gönüllü sayısı ise 20-25 civarındadır (BÜKOOP, 2016).

Ana faaliyetler: Tarımsal ürünlerin aracısız bir şekilde küçük üreticilerden tüketicilere ulaştırılması ana faaliyet alanıdır. Bu ana faaliyeti gerçekleştirebilmek için üretici seçimi, üretici denetimi, fiyatlandırma, kargo, paketleme ve satış faaliyetleri yapılmaktadır.

BÜKOOP’ta 70 civarında ürünün aracısız olarak dağıtım ve satışı yapılmaktadır. Günlük hayatta ekolojik olarak üretilmiş yaş sebze meyve bulmak kuru gida bulmaya kıyasla daha zor olduğu için yaş sebze meyve yüksek oranda ilgi çekmektedir ve BÜKOOP'a yaş sebze meyve geldiğinde genel olarak satışlar artmaktadır. Yaş sebze meyve almak için gelen tüketiciler, yanı sıra kuru gıdalardan da almaktadırlar (BÜKOOP, 2016). Dönemsel olarak ürünler değişmekte olup, sütten, peynire, soğandan, kuru sebzeye, cevizden incire birçok çeşit raflarda yer almaktadır (Öksünlü, 2014).

Topluluğa yeni üreticiler dahil edilirken çeşitli araştırmalar yapılmaktadır. Yeni üreticiler bazen BÜKOOP'u bulmakta, bazen de BÜKOOP ortaklar tarafından aranan ürün doğrultusunda ürün bilgi formu doldurulmakta, ürünün nasıl üretildiği, ilaç kullanıp kullanılmadığı, üreticinin yanında çalışan kişilerin durumu vb. gibi sorular sorulmaktadır. Bu bilgiler doğrultusunda BÜKOOP gönüllüleri toplantılarda yeni üreticileri ve ürünleri değerlendirmektedir. BÜKOOP'a uygun olup olmadığı hem üretim açısından, hem fiyat açısından, hem de BÜKOOP pratiklerine, örneğin kargo, paketleme gibi konulara uyup uymadığ1 açısından değerlendirilmektedir. Ürün sorumluluğunu almaya gönüllü ortak da varsa, yeni üretici katılımı gerçekleşmekte, yeni üreticinin ürünleri hakkında diğer o üreticiyi tanıyan diğer üreticilerden referans alınmaktadır. Yeni üreticinin daha önce ürünlerini laboratuvar testlerini yaptırmış olması seçilmesinin bir diğer göstergesi olmaktadır (BÜKOOP, 2016).

Topluluğa dahil edilecek üreticiler ve ürünler için bir takım net ölçütler vardır. Küçük üretici olup olmadığı, ilaç kullanıp kullanmadığı, nasıl tohum kullandığı, nasıl üretim yaptığı, kooperatif pratiklerine uyum sağlayıp sağlayamayacağı değerlendirilmektedir. Her zaman tüm bu ölçütlerde ideal üreticiyi bulmak mümkün olmasa da, bahsi geçen ölçütlerin bir kısmının sağlanması da duruma göre yeterli kabul edilebilmektedir. Buna örnek vermek gerekirse yerel pazarlardan ürün alarak tarhana, salça vb. üretim yapan kadın derneklerini bu noktada tercih edilebilmektedir (BÜKOOP, 2016).

Üreticilerin denetimi açısından, üreticileri gönüllüler ve tüm BÜKOOP ile ilgilenenler denetleyebilmektedir. Örneğin, kooperatiften alışveriş yapanların soruları olduğunda, ürün sorumlusu gönüllü üreticiyle iletişim kurarak ürün hakkında, üretim hakkında detaylı bilgi alıp paylaşmaktadır. Zaman zaman tarla ziyaretleri, üretici ziyaretleri yaparak üretim süreçleri öğrenmeye çalışılmaktadır. Bir sorunun olduğu fark edildiğinde diğer üreticilerden de destek alarak bu üreticinin sorunu çözülmeye çalışılmaktadır. BÜKOOP gönüllüleri, BÜKOOP mensubu diğer tüketiciler ve zaman zaman da üreticiler kendileri ürünlerini laboratuvar testlerine yollamakta ve bu sayede de ürünler hakkında daha derin bilgi edinilebilmektedir. Çeşitli üreticilerden ve kurumlardan da üreticiler hakkında bilgi toplanmaktadır. BÜKOOP'un denetim süreçlerine bakışı, karşılıklı birbirini tanıma, bilgi paylaşma ve güven inşa etme olarak şekillenmektedir (BÜKOOP, 2016).

Siparişlerin alınması ve üreticiye iletilmesi için kullanılan altyapıya bakıldığında, BÜKOOP, bir iki ürün dışında ürünler için sipariş toplamamaktadır. Siparişler, geçmiş satış istatistikleri, ürünün dayanıklılığı, depolama imkânları, ürünün ortalama kaç günde kooperatifte olacağı gibi ölçütleri göz önünde bulundurularak verilmektedir. Her ürün ya da ürün grubunun bir ürün sorumlusu vardır. Genelde işleri hafifletmek için bir ürüne/ürün grubuna iki ürün sorumlusu sağlamaya çalışılmaktadır. Dropbox ve Google 
Drive üzerinden sipariş ve ödeme takibi yapılmakta, bu ise gönüllülerle paylaşılarak şeffaflık sağlanmaktadır. Üreticilere ya telefon ya da e-posta aracılığı ile ulaşılmaktadır (BÜKOOP, 2016).

BÜKOOP’un satış mekânı, dönem boyunca hafta içi her gün gönüllüler sayesinde öğlen yarım saat ve akşam üstü yarım saat olmak üzere, toplam günde bir saat açıktır. Bu sistem 4 senedir sürdürülmekte olan bir sistemdir. Websitesi, facebook, twitter ve e-posta aracilığıyla duyurular yapılmaktadır. Tanışma toplantıları, yılbaşı kutlamaları, üretici söyleşileri gibi yılda 3-4 kere düzenlenen etkinlikler de vardır. BÜKOOP'un satış mekânı, satış ve dağıtımın yapıldığı, bilginin paylaşıldığı, tüketicinin gönüllülere ya da hatta doğrudan üreticiye sorularını sorabildiği, bir ürünü tadabildiği ya da ürün hakkında endişe veya övgülerini dile getirebildiği bir sosyal kamusal mekândır (BÜKOOP, 2016).

Tüketici ilişkileri türü: Küçük üreticiden tüketiciye aracısız olarak, sağlıklı, adil gıdayı, uygun fiyatla ulaştırmaktır. Sürdürülebilir, herkesin katılımına açık, şeffaf bir örgütlenme olarak tarımdaki kimyasal kullanımından, üreticilerin hapsedildiği kısır döngülere kadar pek çok toplumsal alana müdahale etmeye çalışan, tüketiciyi ve üreticiyi aynı platformda bir araya getirip, ikisinin ayrı taraflarda olmadığını, toplumsal ve ekolojik adaleti sağlamada beraberce çalışabileceklerini iddia eden "güler yüzlü" bir toplumsal örgütlenme şeklidir (Ertör Akyazı, 2015).

Kanallar: Üreticilere, ortaklara ve gönüllülere web sitesi üzerinden bilgiler sunulup iletişime geçilmektedir. Temelde gönüllüler arasında ana iletişim e-posta yolu ile sağlanmaktadır. Ortaklara ve diğer BÜKOOP mensuplarına da duyurular e-posta yolu ile iletilmektedir. Buna ek olarak facebook, twitter ve web sitesi de aktif olarak kullanılmaktadır. Web sitesi ve sosyal medya aracılığı ile yeni gönüllülere, ortaklara ve üreticilere ulaşılabilmektedir.

Segmentler-Faydalanıcılar: BÜKOOP ortakları ve ortak olmayan tüketiciler sağlıklı olarak üretilen gıda maddelerini tüketerek fayda sağlamaktadırlar. Küçük üreticilerden tüketiciye aracısız olarak, sağlıklı, adil gıdayı, uygun fiyatla ulaştırmaya çalışan bir model benimseyen BÜKOOP, bu modeliyle üretim sürecinde sentetik gübre, kimyasal böcek ilaçları, hibrit ve GDO'lu tohumları kullanmayan çiftçileri sistemine dahil etmektedir. Bu tarz, ekolojik, doğayla dost bir tarım yaklaşımını olduğu için çiftçiler ve kullanıcılar sağlıklı ürün üretmekte ve onunla beslenmektedir, beraberinde ekoloji de korunmuş olmaktadır. Bazı durumlarda bu ölçütlere sahip olmayan üreticiler de dahil edilebilir. Örneğin, bir kadın derneğinin yerel üretimini desteklemeye karar verilirse, ürünlerin tamamen ekolojik olması beklenmemektedir. Dolayısıyla ekolojik tarım yapan küçük üretici çiftçiler, sosyal sorunların çözümüne katkıda bulunmak amacıyla çeşitli gruplar, bu ürünleri satın alan ortaklar ve ortak olmayan tüketiciler sosyal olarak bilinçli bireyler olarak bu kooperatifin faaliyetlerinin yararlanıcıları arasındadır.

Değer sunma: BÜKOOP ortaklarına ve tüketicilere sağlıklı, ekolojik gıda ürünlerini sunarak değer sunmaktadır. Üretimlerinde ucuz kimyasallar ve endüstriyel gıda katkı maddeleri kullanmayan küçük üreticilere ise ürünlerini büyük şirketlerle işbirliğine gitmeden tüketiciye aracısız olarak ulaştırma ve kazanç sağlayarak faaliyetlerini devam ettirebilmeleri açısından değer sunmaktadır. Tüm bunlar kâr amacı güdülmeden yapılmaktadır. Ayrıca Katılımcı Sertifikasyon sistemleri ile katılımcı olan küçük üreticilere ürünlerini alma teminatının verilmesiyle yüksek ücretler ödenen organik sertifikasyona alternatif olan bir sistem ile de fayda ve sosyal etki sağlanmaktadır.

Gelir akışları: Gelirler ürün satışlarından ve üyelerin ortak olurken bir sefere özgü yaptıkları ödemelerden sağlanmaktadır. Ürün fiyatları tüm masrafları karşılayacak, kâr ya da zarar etmeden yılı kapamalarını sağlayacak şekilde belirlenmektedir. Ürünün maliyeti üzerine üründen ürüne değişen ancak genelde ürünün satış fiyatının \%13-16 civarına tekabül eden BÜKOOP payı eklenmektedir.

Yatırım planları: BÜKOOP gelir fazlası elde ettiği takdirde bunu kooperatifi büyütmek ve çeşitli şubeler açmak şeklinde değerlendirme amacı taşımamakta ve büyümemeyi tercih etmektedir. Gelir fazlası, büyüme yerine ürün çeşitliliğini arttırma şeklinde değerlendirilebilir. Ayrıca gelecek planları arasında çeşitli toplumsal sorunlarda kullanmak üzere gelir fazlası değerlendirmek de yer almaktadır. Sadece satış amaçlı bir kooperatif olmayan BÜKOOP, bilgi üretimi ve paylaşımını da destekleyerek, kendilerinden yardım ve destek isteyen diğer girişimlere kooperatifin nasıl kurulacağı, nasıl işleyeceği hakkındaki uygulama deneyimlerini kitapçık bastırarak paylaşmayı da planlamaktadırlar (Taşyürek, 2019). Gelecekte gönüllü iş 
gücü yeterli olduğunda ise bilinirliği arttırmak amaçlı olarak ürünlerin e-ticaret yöntemiyle satışını sağlamak da hedeflenmektedir (BÜKOOP, 2016).

Değer akışları, Maliyet yapısı ve Harcama alanları: Mali müşavir dışında ücretli çalışan yoktur. En büyük harcama alanı üreticilerden alınan ürünler karşılığında yapılan ödemelerdir. Ödemeler genellikle üreticilere, ürünün BÜKOOP'a ulaşmasından en geç 1-2 hafta sonra yapılmaktadır. Bu sürede gelen ürünün bir kısmı satılmış olmakta ve nakit akışı da böylece kolaylaşmaktadır. BÜKOOP'ta satılmayacağı düşünülen ürünler baştan üreticiye aktarılmaktadır, dolayısıyla ya bu ürünlerden hiç sipariş verilmemekte ya da belli bir süre sonra sorun olacağı anlaşıldıysa bir sonraki sefer sipariş edilmeyeceği üreticiye bildirilmektedir. Üreticilere senelik talebin ne olacağı olabildiğince ekim dikim yapılmadan önce iletilmeye çalışılmaktadır, böylece üretici de planlamasını buna göre yapabilmektedir. Bu ise BÜKOOP'un üreticileri desteklemekteki en güçlü yanlarından biri olarak ifade edilmektedir. Böylece seneler içerisinde üreticiler ve BÜKOOP arasında güven tesis edilebilmektedir. Riskler de bu güvene dayalı olarak üreticiyle ortak karar alınmak suretiyle paylaşılmaktadır (BÜKOOP, 2016).

\section{Sonuç}

Bu çalışmada, gıda alanındaki küçük üreticileri tüketiciler ile aracılar olmaksızın buluşturan alternatif bir iş modeli biçimlendiren ve farklı örgütlenme biçimleri sergileyen bir STK olan Boğaziçi Üniversitesi Tüketim Kooperatifi (BÜKOOP) incelenmiştir. BÜKOOP, yeni sosyal iş modelini sosyal girişimcilik ile hayata geçirirken ne amaçla ve hangi tür çalışmaları yaptıkları, bu çalışmaları nasıl yaptıkları örnek olay yöntemi kullanılarak incelenmiştir. BÜKOOP'un nasıl ve ne amaçla başlatıldığı, hayata geçirirken hangi tür çalışmaların yapıldığı, bu çalışmaların nasıl yapıldığı, girişimin örgüt yapısı ve faaliyetleri ortaya konmaya çalışılmıştır. Bu yapılırken Tracey, Phillips ve Jarvis'in (2011) kurumsal girişimcilerin yeni bir örgüt formu oluşturmaları sırasında yapmış oldukları çalışmalara odaklanarak geliştirdikleri modelden yararlanılmıştır. Ayrıca Sosyal İş Modeli Kanvas'ından (Kent State University, 2019) ve Osterwalder ve Pigneur'un (2010) iş modeli kanvasından yararlanarak BÜKOOP sosyal iş modeli elde edilen veriler çerçevesinde açıklanmaya çalışılmıştır.

Sosyal girişimcilik sadece tek başına kahraman aktörleri değil aynı zamanda girişimci grupları, ağları ve kuruluş ittifaklarını da Heinze, Banaszak-Holl, ve Babiak (2016: 316) içermektedir. Seelos ve Mair'e göre (2005: 241) sosyal girişimcilik mevcut pazarların ve kurumların tatmin edemediği insan ihtiyaçlarına odaklanıp, bu ihtiyaçları etkin bir şekilde karşılamaya yönelmiş olan kuruluşları da ifade etmektedir. Dolayısıyla Boğaziçi Üniversitesi mensupları tarafından kurulan ve sağlıklı gıdayı uygun fiyatla aracısız olarak tüketiciye sunmayı amaçlayan ve bu çalışmaları yerine getiren BÜKOOP'un sosyal girişimci bir yapıda olduğu ifade edilebilir. Kü̈cük üretici olan çiftçiler sertifikalı organik gıda üreten büyük üreticilerle rekabet edememektedir, zira organik ürün üretmek, organik sertifika sağlayan kurumlarla çalışma zorunluluğunun olmasını ve bunu yapabilmek için de çok ciddi bir harcama yapılmasını gerektirmektedir. Büyük organik gıda üreticileri ürünlerini yüksek fiyatlarda piyasaya sunmaktadırlar ve tüketiciler eşit bir şekilde organik gıda tüketme şansına sahip olamamaktadırlar. BÜKOOP bu noktada katkı maddesi kullanılmayan ve pestisitle ilaçlanmamış ürün üreten küçük üreticilere destek olarak ve organik ve sağlıklı gıdaya ulaşmak isteyen tüketicilere aracısız olarak bu ürünleri sunup yardımcı olarak yerel kapasite geliştirmiş ve bu grupların hayatlarını iyileştirmek için harekete geçmiş (Alvord, v.d., 2003: 144) bir kooperatiftir. Ayrıca eğer bir gelir fazlası elde edilirse bu ürün çeşitliliğini arttırmaya odaklı kullanılmaktadır ve ileride elde edilebilecek daha fazla gelir fazlasını toplumsal konularda kullanılmak istenmektedir. Dolayısıyla ekonomik, politik ve kültürel dönüşümünde kaldıraç kuvvetine sahip olabilecek (Van Slyke ve Newman, 2006: 349) başarılı bir sosyal girişimci adayıdır.

BÜKOOP bir sosyal girişimci olarak oluşturduğu tüketim kooperatifi modelinde mevcut çözümlerden daha etkili bir şekilde bir sosyal ihtiyacı karşıladığı ve yeni yeteneklere ve ilişkilere yol açtığı için varlık ve kaynakların daha iyi kullanılmasını sağlayarak (Caulier-Grice vd., 2012: 18) bir sosyal inovasyona imza atmıştır. Oluşturdukları sosyal iş modelinde üretici ile ilişkiler ve üreticilerin seçimi, kooperatif üyelerinin kendi aralarında iletişimi ve kooperatif çalışmalarının yerine getirilişi, gönüllülerle kurulan ilişkiler ve ürünün tüketiciye sunulma şekli itibariyle aracısız ürün ağını kurarak sosyal bir ihtiyacı karşılayıp yeni ilişkilere yol açmıştır. Böylelikle toplumun harekete geçme kapasitesini artıırıcı faaliyetlerin gerçekleştirilmesine zemin hazırlamış oldukları ifade edilebilir. 


\section{Ç. Kaya 11/3 (2019) 1433-1449}

Çelik (2016), yaklaşık 15 civarında gıda topluluğu ile yapmış olduğu aracısız ürün analizi ile ilgili çalışmasında, gıda toplulukları ve aracısız ürün ağlarının felsefeleri gereği, tüketicilerin mevsiminde, sağlıklı ve doğal gıdaya erişimini sağlamakta olduklarını belirtmiştir. Bu gıda toplulukları sisteminin, önemli bir pazarlama stratejisi olan etiketler ve çeşitli sertifikalar yerine, üreticiyi tanıma ve karşılıklı güven, tüketici olarak üretimdeki sorumluluğunun bilincinde olmalarının en önemli özellikleri olduğunu belirtmiştir. Ancak küreselleşme ve şehirleşmenin hızla ilerlediğini, alışkanlıklar, algılar, değerlerin değiştiğini, kolaycılık ve hızın her şeyin önüne geçtiğini eklemiştir. $\mathrm{Bu}$ nedenlerle bu alternatif sistemin sürdürülebilirliği açısından, tüketicilerin bilgi, algı, alışkanlık ve değerlerini değiştirmeye yönelik faaliyetlerin gerçekleştirilmesi gerekliliğinin altını çizmektedir.

Sonuç olarak bu çalışmada sosyal girişimcilik yoluyla yeni bir sosyal iş modelinin oluşturulmasına odaklanılmıştır. Tracey, Phillips ve Jarvis'in (2011:78), yeni bir örgütsel formun geliştirilmesinde önemli olan kurumsal çalışma türlerinin, başka tür kurumlar için de geçerli olup olmadığının araştırılmasının öneminin altını çizmişlerdir. Yapılan bu araştırmada sosyal girişimcilerin yeni bir sosyal bir iş modeli oluştururken yapmış oldukları çalışmalar ile Tracey, Phillips ve Jarvis'in (2011) modellerinde sunmuş oldukları kurumsal çalışma türleri birbirine paralellik göstermektedir.

Gelecek çalışmalar BÜKOOP sonrası kurulan diğer tüketim kooperatiflerini de çalışmaya dahil ederek daha bütüncül bir yaklaşım elde edebilirler. Yapılacak bu çalışmalarda anket formları kullanılarak niceliksel araştırma yapılabilir ve ölçümler elde edilebilir. Bununla birlikte, benzer sosyal girişimcilik süreçlerinin, girişimciler tarafından başka türden kurumlar yaratmaya çalıştıklarında da kullanılıp kullanılamayacağı araştırılabilir (Tracey, Phillips ve Jarvis, 2011:78). Son olarak zaman içerisinde tüketim kooperatiflerinin değişimi ve gelişimi görebilmek adına boylamsal çalışmalar yapılabilir.

\section{Kaynakça}

1163 Sayılı Kooperatifler Kanunu, www.mevzuat.gov.tr/MevzuatMetin/1.5.1163.doc , Erişim Tarihi: 26.04.2018.

Alvarez, S. A., ve Barney, J. B. (2014). Entrepreneurial Opportunities and Poverty Alleviation, Entrepreneurship Theory and Practice, 38 (1): 159-84.

Alvord, S. H., Brown, L. D., ve Letts, C. W. (2003). Social Entrepreneurship: Leadership That Facilitates Societal Transformation- An Exploratory Study, Cambridge, Mass. Center for Public Leadership, Kennedy School of Government, Harvard University, https://dspace.mit.edu/handle/1721.1/55803 14.02.2019 (Erişim Tarihi: 07.06.2018).

Alvord, S. H., L. D. Brown, ve C. W. Letts. (2004). Social Entrepreneurship and Societal Transformation: An Exploratory Study, Journal of Applied Behavioral Science, 40 (3): 260-82.

Atayeter, C., Özilhan, D. ve Aslan, Ş. (2004). Sivil Toplum Kuruluşlarında Bilgi Teknolojileri Kullanımının Örgüt Yapısı ve Performansına Etkileri, Çanakkale 18 Mart Üniversitesi, I. STK Kongresi, Bildiriler Kitabi, 27-34.

Bielefeld, W. (2009). Issues in Social Enterprise and Social Entrepreurship, Journal of Public Affairs Education, 15 (1): 69-86.

Bielefeld, W. (2008). Social Entrepreneurship and Social Enterprise, Wankel, C. (Ed.), 21st Century Management, Thousand Oaks, CA, Sage, 22-31.

BÜKOOP (2014). BÜKOOP Bir Heyecandır, https://bukoop.org/yazilar/bukoop-bir-heyecandir/ , (Erişim Tarihi: 07.06.2018).

BÜKOOP (2014). Neden BÜKOOP, https://bukoop.org/hakkimizda/ , (Erişim Tarihi: 06.06.2018).

BÜKOOP (2016). BÜKOOP modelinde lojistik, dağıtım, gönüllülük, https://bukoop.org/yazilar/bukoopmodelinde-lojistik-dagitim-gonulluluk/, (Erişim Tarihi: 06.06.2018).

Caulier-Grice J, Davies A, Patrick R, ve Norman, W. (2012). Social innovation overview: a deliverable of the project: "The theoretical, empirical and policy foundations for building social innovation in Europe" (TEPSIE), European Commission - 7th framework programme. European Commission, DG Research, Brussels.

Choi, N. ve Majumdar, S. (2015). Social Innovation: Towards a Conceptualisation, Majumdar, S.; Guha, S.; Marakkath, N. (Ed.), Technology and Innovation for Social Change, India, Springer, 7-34. 


\section{Ç. Kaya 11/3 (2019) 1433-1449}

Cumhuriyet Gazetesi (2018). Tüketici Kooperatifleri: Topraktan Sofraya Aracısız Gıda (Abdullah Aysu Röportaj1),

http://www.cumhuriyet.com.tr/haber/ekonomi/924596/Topraktan sofraya aracisiz gida.html, (Erişim Tarihi: 07.06.2018).

Çelik, Z. (2016). Gıda Toplulukları ve Aracısız Ürün Ağı Analizi, Meyve Bilimi Dergisi, Meyvecilik Araştırma Enstitüsü, 1 (Özel Say1): 26-32.

Çetin, M. (2004). Sivil Toplum Kuruluşlarında Liderin Başarıya Etkisi ve Kurumsallaşma, http://sistem.ie.metu.edu.tr/stklardailiderlik.htm, (Erişim Tarihi: 03.04.2018).

Dacin, M. T., Dacin, P. A. ve Tracey, P. (2011). Social Entrepreneurship: A Critique and Future Directions, Organization Science, 22 (5): 1203-1213.

Dallı, C. M. (2015). Özgün Bir Kooperatifçilik Deneyimi: BUKOOP, Birikim Dergisi, http://www.birikimdergisi.com/haftalik/1342/ozgun-bir-kooperatifcilik-deneyimibukoop\#.XHiDA4gzYdU, (Erişim Tarihi: 01.03.2019).

de Rooij, S. M., Özgüzel, S. ve Bilgin, K. U. (2017). Türk Kooperatif Yönetim Performansına Etkisi Açısından Toplumsal İletişim Ağı: Kooperatifçilikte Hollanda Örneği “Nautilius”, Üçüncü Sektör Sosyal Ekonomi, 52: Özel Sayı: 811-835.

Dees JG, ve Anderson B. (2006). Framing a theory of social entrepreneurship: building on two schools of practice and thought. Research on Social Entrepreneurship. ARNOVA Occas Paper Ser, 1 (3):39-66

Eisenhardt, K. M. ve Graebner, M. E. (2007). Theory building from cases: Opportunities and challenges. Academy of Management Journal, 50(1), 25-32.

Ertör Akyazı, P. (2015). Bir alternatif iktisadi model olarak BÜKOOP, https://bukoop.org/yazilar/biralternatif-iktisadi-model-olarak-bukoop/, (Erişim Tarihi: 21.02.2019).

Güloğlu, T. ve Es, M. (2006). Sivil Toplum Kuruluşlarının Yerel Yönetimlere Etkisi, Çanakkale 18 Mart Üniversitesi, III. Uluslararası STK'lar Kongresi, Bildiri Kitabı, s. 147-154.

Heinze, K. L. Banaszak-Holl, J.,ve Babiak, K. (2016). Social Entrepreneurship in Communities: Examining the Collaborative Processes of Health Conversion Foundations, Nonprofit Management \& Leadership, 26 (3): 313-330.

Heinze, K. L. Banaszak-Holl, J.,ve Babiak, K. (2016). Social Entrepreneurship in Communities: Examining the Collaborative Processes of Health Conversion Foundations, Nonprofit Management \& Leadership, 26 (3): 313-330.

Kent State University (2019). Social Enterprise Business Model Canvas, https://www.kent.edu/sites/default/files/file/SocialEnterpriseCanvas-VAM\%20tool.pdf, (Erişim Tarihi: 01.03.2019).

Kurtiç, E. (2014). Ne istiyoruz: Gıda Egemenliği! Ne zaman: Hemen şimdi!, Boğaziçi Üniversitesi Mensupları Tüketim Kooperatifi Bülteni, Sayı $10, \quad$ https://bukoop.org/wpcontent/uploads/sites/2/2015/03/BuKoop Bulten Sayi 10.pdf, (Erişim Tarihi: 01.03.2019).

Light, P. (2008). The Search for Social Entrepreneurship. Washington, DC: Brookings Institution.

Light, P. C. (2006). Reshaping social entrepreneurship, Stanford Social Innovation Review, 4(3), 46-51.

Mair, J., ve Marti, I.. (2006). Social entrepreneurship research: A source of explanation, prediction, and delight, Journal of World Business, 41(1), 36-44.

Martin, R. L., ve Osberg, S. (2007). Social Entrepreneurship: The Case for Definition, Stanford Social Innovation Review, 5 (2), 28-39.

Montgomery, A. W., ve Dacin. P. A. (2012). Collective Social Entrepreneurship: Collaboratively Shaping Social Good, Journal of Business Ethics, 111 (3), 375-388.

Murphy, P. J. ve Coombes, S. M. (2008). A Model of Social Entrepreneurial Discovery, Journal of Business Ethics, 87, 325-336.

Murphy, P. J., ve Coombes, S. M. (2009). A Model of Social Entrepreneurial Discovery, Journal of Business Ethics, 87 (3), 325-336. 


$$
\text { Ç. Kaya 11/3 (2019) 1433-1449 }
$$

Navasaitiene, S., Vishniakova, M., ve Rukuiziene, R. (2016). New Motives and Models for Creation Social Business in the Republic of Belarus, Management Theory and Studies for Rural Business and Infrastructure Development, 38 (4), 403-411.

Nicholls, A., ve Cho, A. H. (2006). Social Entrepreneurship: The Structuration of a Field, Nicholls, A. (Ed.), Social Entrepreneurship: New Models of Sustainable Social Change, Oxford, Oxford University Press, 99118.

Osterwalder, A. ve Pigneur, Y. (2010) Business Model Generation. New Jersey, Wiley.

Öksünlü, D. (2014). BÜKOOP ile topraktan soframıza, https://haberler.boun.edu.tr/tr/haber/bukoop-iletopraktan-soframiza, (Erişim Tarihi: 07.06.2018).

Saruhan, Ş. C. (2017). Çağdaş Yönetim Bilimi, İstanbul, Beta Yayınları, 3. Baskı

Seelos, C., ve Mair, J. (2005). Social Entrepreneurship: Creating New Business Models to Serve the Poor, Business Horizons, 48 (3), 241-46.

Seelos, C., ve Mair, J. (2005). Social entrepreneurship: Creating new business models to serve the poor, Business Horizons, 48 (3), 241-246.

Spear, R. 2006. Social Entrepreneurship: A Different Model, International Journal of Social Economics 33 (5/6), 399-410.

Swedberg, R. (2009). Schumpeter's full model of entrepreneurship: economic, non-economic and social entrepreneurship, Ziegler, R. (Ed), An introduction to social entrepreneurship: voices, preconditions, contexts, Edward Elgar, Cheltenham, 77-106,

Taş, İ. ve Şemşek, H. Y. (2017). Türkiye ve Dünya'dan Sosyal Girişimcilik Örnekleri ve İstihdama Katkıları, Emek ve Toplum, 6 (16), 480-497.

Taşyürek, A. (2019). Yerel, adil, temiz, sağlıklı gıda: Bükoop-Ferit Öztürk, Asya Saydam ve Serkan Kaptan ile mülakat, http://www.bantmag.com/magazine/issue/post/29/246, (Erişim Tarihi: 21.02.2019).

Teece, D. J. (2010). Business Models, Business Strategy and Innovation, Long Range Planning, 43, 172-194.

TEPSIE (2014). Social Innovation Theory and Research: A Summary of the Findings from TEPSIE, A deliverable of the project: "The theoretical, empirical and policy foundations for building social innovation in Europe" (TEPSIE), European Commission - 7th Framework Programme, Brussels: European Commission, DG Research.

The Social Business Model (2015). How to Choose Proper Business Model for Social Enterprise, The Social Entrepreneurship Development, http://socialinnovation.lv/wp-content/uploads/2015/07/Businessmodel-webam-small.pdf, (Erişim Tarihi: 15.02.2019).

Tracey, P., Phillips, N. ve Jarvis, O. (2011). Bridging Institutional Entrepreneurship and the Creation of New Organizational Forms: A Multilevel Model, Organization Science, 22(1), 60-80.

Van Slyke, D. M., ve Newman, H. K. (2006). Venture Philanthropy and Social Entrepreneurship in Community Redevelopment, Nonprofit Management and Leadership, 16 (3), 345-68.

Yin, R. K. (2009). Case Study Research: Design and Methods (4th ed.), Thousand Oaks, CA, SAGE Publications.

Zahra, S. A., Gedajlovic, E., Neubaum, D. O. ve Shulman, J. M. (2009). A Typology of Social Entrepreneurs: Motives, Search Processes and Ethical Challenges, Journal of Business Venturing, 24, 519-534. 